Supplementary Information

\title{
Metal-Dependent DNA Base Pairing of 5-Carboxyuracil with Itself and All Four Canonical Nucleobases
}

Yusuke Takezawa, Akira Suzuki, Manabu Nakaya, Kotaro Nishiyama, and Mitsuhiko Shionoya*

Department of Chemistry, Graduate School of Science, The University of Tokyo, 7-3-1 Hongo, Bunkyo-ku, Tokyo 113-0033, Japan

\section{Table of Contents}

1. Materials and methods

1-1. DNA synthesis

1-2. Experimental procedures for the measurements

2. Supplementary figures

3. Supplementary tables

4. References 


\section{Materials and methods}

\section{1-1. DNA synthesis}

DNA strands containing 5-carboxyuracil (caU) nucleobases were synthesized on an

NTS M-2-MX DNA/RNA synthesizer. A phosphoramidite derivative of caU deoxyribonucleoside, in which the 5-carboxy group was protected by an ethyl ester, was prepared according to reported procedures. ${ }^{1,2}$ The DNA synthesis was carried out on a $1-\mu$ mol scale in a DMTr-on mode with ultramild deprotection phosphoramidites and reagents (Glen Research). The coupling time of caU was extended to $15 \mathrm{~min}$. The products were cleaved from the solid supports and deprotected using $0.3 \mathrm{M} \mathrm{NaOH}$ aqueous solution at $37^{\circ} \mathrm{C}$ for $24 \mathrm{~h}$. The oligonucleotides were firstly purified and detritylated using a Glen-Pak cartridge (Glen Research) and further purified by reverse-phase HPLC (Waters XBridge C18 column, buffers: $\mathrm{A}=\mathrm{MeCN}, \mathrm{B}=0.1 \mathrm{M}$ TEAA $(\mathrm{pH} 7.0)+2 \% \mathrm{MeCN}$, flow rate: $0.5 \mathrm{~mL} \mathrm{~min}$, temperature: $60{ }^{\circ} \mathrm{C}$ ). All DNA strands were identified by ESI-TOF mass spectrometry. Unmodified oligonucleotides purified by HPLC were purchased from Japan Bio Services and used without further purification. The amount of the oligomers was determined based on the UV absorbance at $260 \mathrm{~nm}$. The molar extinction coefficients $\left(\varepsilon_{260}\right)$ of the oligonucleotides were calculated by the nearest-neighbor method. We assumed the $\varepsilon_{260}$ value of caU nucleotides is $7.7 \times 10^{3} \mathrm{M}^{-1} \mathrm{~cm}^{-1}$, which was experimentally determined for the caU mononucleoside at $\mathrm{pH}$ 7.0.

Oligonucleotide 1. 5'-CAC ATT caUGT TGT A-3'. HPLC retention time: $26.2 \mathrm{~min}$ (gradient: 4\%A (0 min), 7\%A (30 min)). ESI MS: $m / z$ calcd for $\left[\mathrm{C}_{128} \mathrm{H}_{161} \mathrm{~N}_{43} \mathrm{O}_{81} \mathrm{P}_{12}-6 \mathrm{H}\right]^{6-}$ : 660.44; found: $660.42 . \varepsilon_{260}=1.26 \times 10^{5} \mathrm{M}^{-1} \mathrm{~cm}^{-1}$.

Oligonucleotide 2. 5'-TAC AAC caUAA TGT G-3'. HPLC retention time: $25.8 \mathrm{~min}$ (gradient: $4 \% \mathrm{~A}(0 \mathrm{~min}), 6 \% \mathrm{~A}(40 \mathrm{~min})$ ). ESI MS: $\mathrm{m} / z$ calcd for $\left[\mathrm{C}_{128} \mathrm{H}_{159} \mathrm{~N}_{49} \mathrm{O}_{77} \mathrm{P}_{12}-4 \mathrm{H}\right]^{4-}$ : 995.67; found: $995.61 . \varepsilon_{260}=1.33 \times 10^{5} \mathrm{M}^{-1} \mathrm{~cm}^{-1}$.

Oligonucleotide 3. 5'-CAC ATT caUcaUcaU GTT GTA-3'. HPLC retention time: $44.8 \mathrm{~min}$ (gradient: 4\%A (0 min), 6\%A (50 min)). ESI MS: $m / z$ calcd for $\left[\mathrm{C}_{148} \mathrm{H}_{183} \mathrm{~N}_{47} \mathrm{O}_{99} \mathrm{P}_{14}-5 \mathrm{H}\right]^{5-}$ : 926.53; found: $926.27 . \varepsilon_{260}=1.44 \times 10^{5} \mathrm{M}^{-1} \mathrm{~cm}^{-1}$.

Oligonucleotide 4. 5'-TAC AAC caUcaUcaU AAT GTG-3'. HPLC retention time: $28.3 \mathrm{~min}$ (gradient: 4\%A (0 min), 6\%A (40 min)). ESI MS: $m / z$ calcd for $\left[\mathrm{C}_{148} \mathrm{H}_{181} \mathrm{~N}_{53} \mathrm{O}_{95} \mathrm{P}_{14}-4 \mathrm{H}\right]^{4-}$ : 1162.93; found: $1162.87 . \varepsilon_{260}=1.51 \times 10^{5} \mathrm{M}^{-1} \mathrm{~cm}^{-1}$. 
Oligonucleotide 5. 5'-CAC ATT caUcaUG TTG TA-3'. HPLC retention time: $15.3 \mathrm{~min}$ (gradient: $0 \% \mathrm{~A}(0 \mathrm{~min}), 15 \% \mathrm{~A}(20 \mathrm{~min})$ ). ESI MS: $\mathrm{m} / z$ calcd for $\left[\mathrm{C}_{138} \mathrm{H}_{172} \mathrm{~N}_{45} \mathrm{O}_{90} \mathrm{P}_{13}-9 \mathrm{H}\right]^{9-}$ : 477.07; found: $477.05 . \varepsilon_{260}=1.33 \times 10^{5} \mathrm{M}^{-1} \mathrm{~cm}^{-1}$.

Oligonucleotide 6. 5'-TAC AAC caUcaUA ATG TG-3'. HPLC retention time: $15.6 \mathrm{~min}$ (gradient: $0 \% \mathrm{~A}(0 \mathrm{~min}), 15 \% \mathrm{~A}(20 \mathrm{~min})$ ). ESI MS: $m / z$ calcd for $\left[\mathrm{C}_{138} \mathrm{H}_{170} \mathrm{~N}_{51} \mathrm{O}_{86} \mathrm{P}_{13}-7 \mathrm{H}\right]^{7-}$ : 616.24; found: $616.23 . \varepsilon_{260}=1.40 \times 10^{5} \mathrm{M}^{-1} \mathrm{~cm}^{-1}$.

Oligonucleotide 7. 5'-CAC ATT caUcaUcaU caUGT TGT A-3'. HPLC retention time: 15.5 min (gradient: $0 \% \mathrm{~A}(0 \mathrm{~min}), 15 \% \mathrm{~A}(20 \mathrm{~min})$ ). ESI MS: $m / z$ calcd for $\left[\mathrm{C}_{158} \mathrm{H}_{194} \mathrm{~N}_{49} \mathrm{O}_{108} \mathrm{P}_{15}-\right.$ $9 \mathrm{H}]^{9-}:$ 551.41; found: 551.41. $\varepsilon_{260}=1.49 \times 10^{5} \mathrm{M}^{-1} \mathrm{~cm}^{-1}$.

Oligonucleotide 8. 5'-TAC AAC caUcaUcaU caUAA TGT G-3'. HPLC retention time: 15.9 min (gradient: $0 \% \mathrm{~A}(0 \mathrm{~min}), 15 \% \mathrm{~A}(20 \mathrm{~min})$ ). ESI MS: $m / z$ calcd for $\left[\mathrm{C}_{158} \mathrm{H}_{192} \mathrm{~N}_{55} \mathrm{O}_{104} \mathrm{P}_{15}-\right.$ $10 \mathrm{H}]^{10-}: 497.97$; found: 497.96. $\varepsilon_{260}=1.56 \times 10^{5} \mathrm{M}^{-1} \mathrm{~cm}^{-1}$.

Oligonucleotide 9. 5'-CAC ATT caUcaUcaU caUcaUG TTG TA-3'. HPLC retention time: $48.5 \mathrm{~min}$ (gradient: $4 \% \mathrm{~A}(0 \mathrm{~min}), 6.7 \% \mathrm{~A} \quad(60 \mathrm{~min}))$. ESI $\mathrm{MS}: \mathrm{m} / \mathrm{z}$ calcd for $\left[\mathrm{C}_{168} \mathrm{H}_{205} \mathrm{~N}_{51} \mathrm{O}_{117} \mathrm{P}_{16}-5 \mathrm{H}\right]^{5-}: 1060.14$; found: 1060.13. $\varepsilon_{260}=1.56 \times 10^{5} \mathrm{M}^{-1} \mathrm{~cm}^{-1}$.

Oligonucleotide 10. 5'-TAC AAC caUcaUcaU caUcaUA ATG TG- 3 '. HPLC retention time: $48.0 \mathrm{~min}$ (gradient: $4 \% \mathrm{~A}(0 \mathrm{~min}), 6.7 \% \mathrm{~A} \quad(60 \mathrm{~min})$ ). ESI $\mathrm{MS}: \mathrm{m} / \mathrm{z}$ calcd for $\left[\mathrm{C}_{168} \mathrm{H}_{203} \mathrm{~N}_{57} \mathrm{O}_{113} \mathrm{P}_{16}-6 \mathrm{H}\right]^{6-}: 886.29$; found: 886.27. $\varepsilon_{260}=1.63 \times 10^{5} \mathrm{M}^{-1} \mathrm{~cm}^{-1}$.

\section{1-2. Experimental procedures for the measurements}

Metal sources. Metal sources were purchased from Fujifilm Wako Pure Chemical Corporation ( $\mathrm{MnCl}_{2} \cdot 4 \mathrm{H}_{2} \mathrm{O}$ (99\% purity), $\mathrm{FeCl}_{2} \cdot 4 \mathrm{H}_{2} \mathrm{O}$ (99.9\%), $\mathrm{CoCl}_{2} \cdot 6 \mathrm{H}_{2} \mathrm{O} \quad$ (99.5\%), $\left.\mathrm{NiCl}_{2} \cdot 6 \mathrm{H}_{2} \mathrm{O}(99.9 \%), \mathrm{CuCl}_{2} \cdot 2 \mathrm{H}_{2} \mathrm{O}(99.9 \%), \mathrm{AgNO}_{3}(99.8 \%), \mathrm{Hg}\left(\mathrm{ClO}_{4}\right)_{2} \cdot 6 \mathrm{H}_{2} \mathrm{O}(98 \%)\right)$ and Soekawa Chemical Co. $\left(\mathrm{ZnSO}_{4} \cdot 7 \mathrm{H}_{2} \mathrm{O}(99.9 \%), \mathrm{GdCl}_{3} \cdot 6 \mathrm{H}_{2} \mathrm{O}(99.9 \%)\right)$.

Sample preparation. All samples for the spectroscopic studies were prepared by mixing the DNA strands $(2 \mu \mathrm{M})$ in $10 \mathrm{mM}$ HEPES buffer (pH 7.0) containing $100 \mathrm{mM} \mathrm{NaCl}$ or $\mathrm{NaNO}_{3}$. After addition of metal ions, the solutions were heated to $60{ }^{\circ} \mathrm{C}$ and cooled slowly to $4{ }^{\circ} \mathrm{C}$ at the rate of $-1.0{ }^{\circ} \mathrm{C} \min ^{-1}$.

Melting analysis. Absorbance at $260 \mathrm{~nm}$ was monitored by a UV-1700 spectrophotometer (Shimadzu) equipped with a TMSPC-8 temperature controller while the temperature was raised from $4{ }^{\circ} \mathrm{C}$ to $60{ }^{\circ} \mathrm{C}$ at the rate of $0.2{ }^{\circ} \mathrm{C} \mathrm{min}^{-1}$. A drop of mineral oil was laid on the sample to prevent evaporation. Normalized absorbance shown in the Figures were calculated as follows: 
Normalized $\Delta A_{260}=\left\{A_{260}\left(t^{\circ} \mathrm{C}\right)-A_{260}\left(4^{\circ} \mathrm{C}\right)\right\} /\left\{A_{260}\left(60{ }^{\circ} \mathrm{C}\right)-A_{260}\left(4{ }^{\circ} \mathrm{C}\right)\right\} \times 100$.

The melting temperature $\left(T_{\mathrm{m}}\right)$ was determined as an inflection point of a melting curve using a $T_{\mathrm{m}}$ analysis software LabSolutions (Shimadzu) with a 17-point adaptive smoothing program. Average $T_{\mathrm{m}}$ values of at least 3 independent runs were calculated.

CD spectra. CD spectra were recorded on a JASCO J-820 spectropolarimeter with 10-time accumulation using a path length of $1.0 \mathrm{~cm}$ at $5{ }^{\circ} \mathrm{C}$. The spectra were smoothed using a simple moving average smoothing program.

Mass spectra. Electrospray ionization-time-of-flight (ESI-TOF) mass spectra were recorded on a Waters Micromass LCT premier. The samples were prepared in $20 \mathrm{mM} \mathrm{NH}_{4} \mathrm{OAc}$ buffer (pH 7.0) and annealed just before the measurements (from $60{ }^{\circ} \mathrm{C}$ to $4{ }^{\circ} \mathrm{C},-1.0^{\circ} \mathrm{C} \mathrm{min}^{-1}$ ).

\section{Supplementary figures}

(a)

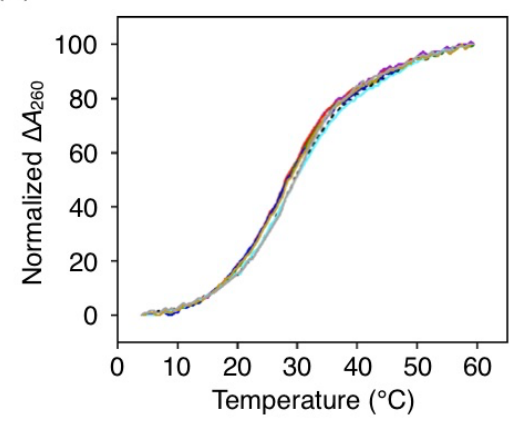

(b)

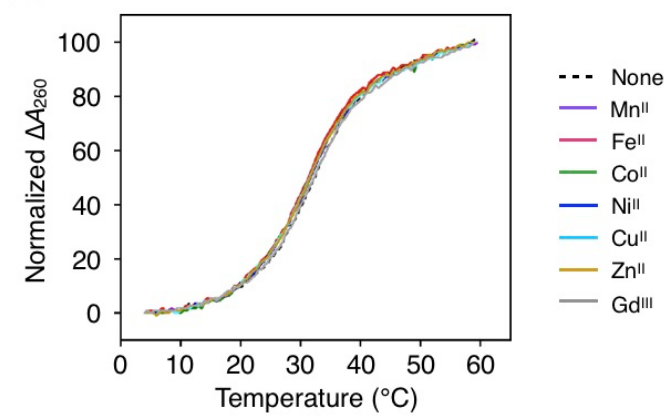

Figure S1. Melting curves of (a) DNA duplex 1.2 and (b) duplex 1T·2T in the presence of various metal ions. $[$ duplex $]=2.0 \mu \mathrm{M}$, [metal ion] $/[$ duplex $]=0$ (dotted lines) or 1 (solid lines) in $10 \mathrm{mM}$ HEPES buffer (pH 7.0), $100 \mathrm{mM} \mathrm{NaCl}, 0.2{ }^{\circ} \mathrm{C} \mathrm{min}^{-1}$.

(a)

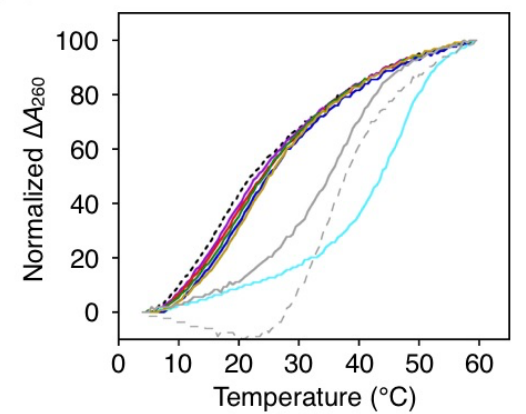

(b)

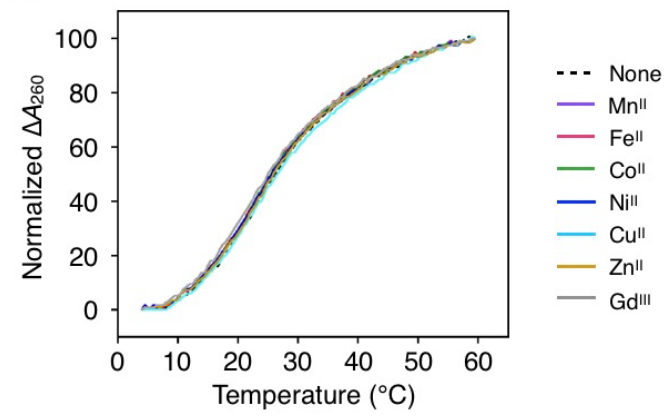

Figure S2. Melting curves of (a) DNA duplex 3.4 and (b) duplex 3T·4T in the presence of various metal ions. $[$ duplex $]=2.0 \mu \mathrm{M}$, [metal ion] $/[$ duplex $]=0$ (dotted lines) or 3 (solid lines) in $10 \mathrm{mM}$ HEPES buffer ( $\mathrm{pH} 7.0$ ), $100 \mathrm{mM} \mathrm{NaCl}, 0.2{ }^{\circ} \mathrm{C} \mathrm{min}^{-1}$. In (a), a melting curve in the presence of $\mathrm{Hg}^{\mathrm{II}}$ ions is overlaid for comparison (gray broken line). Note that the measurement with $\mathrm{Hg}^{\mathrm{II}}$ was carried out under a different buffer condition (see Figure S21). 
(a)

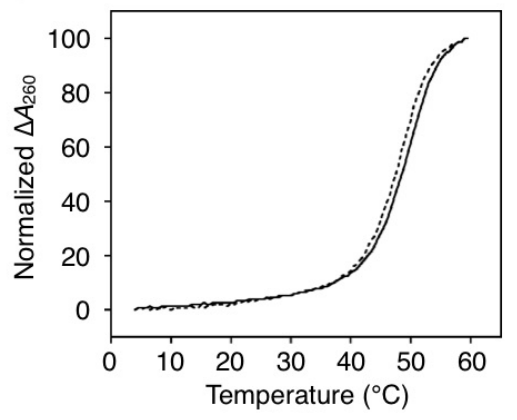

(b)

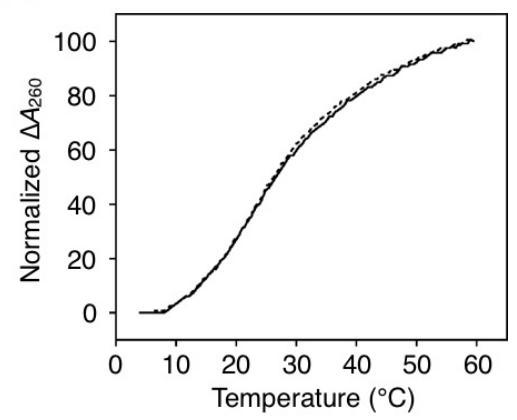

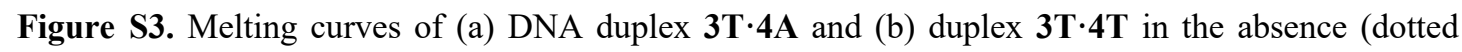
lines) and in the presence (solid lines) of 3 equiv of $\mathrm{Cu}^{\mathrm{II}}$ ions. [duplex] $=2.0 \mu \mathrm{M}$ in $10 \mathrm{mM}$ HEPES buffer (pH 7.0), $100 \mathrm{mM} \mathrm{NaCl}, 0.2^{\circ} \mathrm{C} \mathrm{min}^{-1}$.

(a)

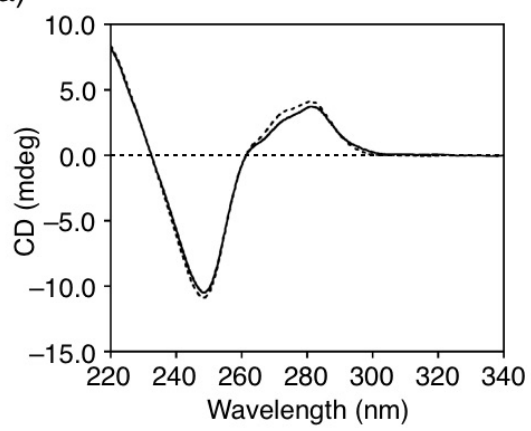

(b)

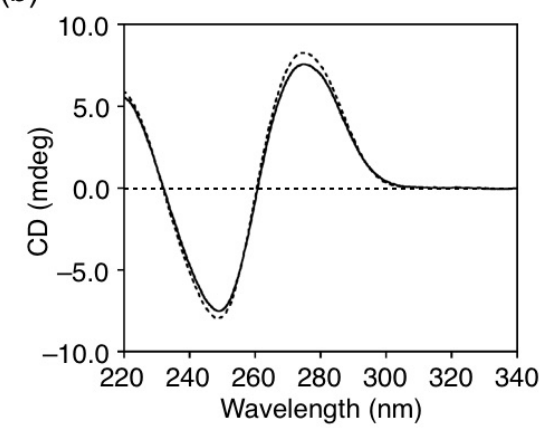

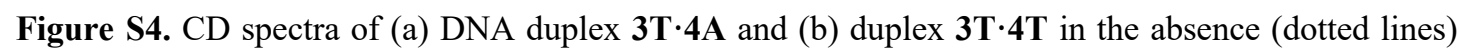
and presence (solid lines) of 3 equiv of $\mathrm{Cu}^{\mathrm{II}}$ ions. [duplex] $=2.0 \mu \mathrm{M}$ in $10 \mathrm{mM}$ HEPES buffer $(\mathrm{pH} 7.0)$, $100 \mathrm{mM} \mathrm{NaCl}, l=1.0 \mathrm{~cm}, 5^{\circ} \mathrm{C}$.

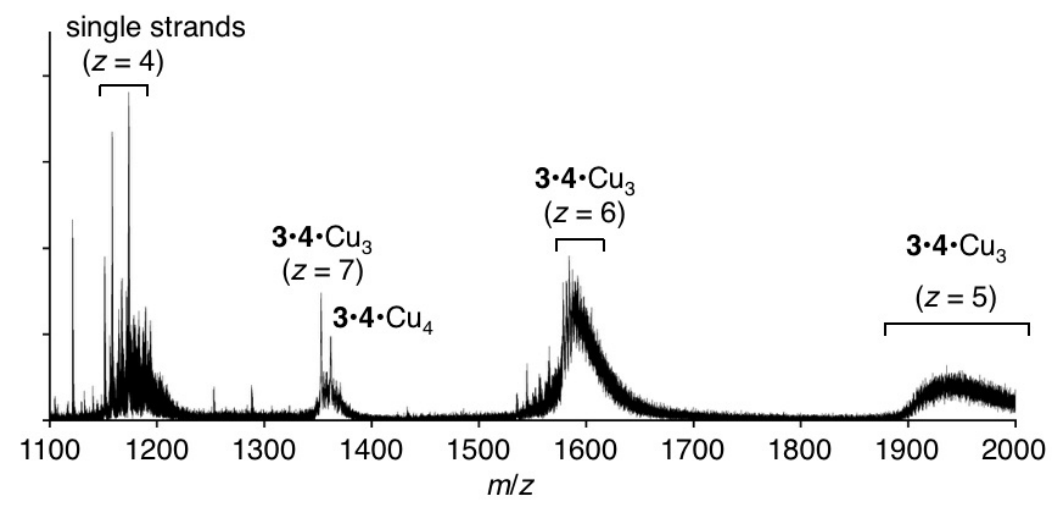

Figure S5. ESI-TOF mass spectrum of metallo-DNA duplex $\mathbf{3} \cdot \mathbf{4} \cdot \mathrm{Cu}_{3}^{\mathrm{II}_{3}} \mathbf{3} \cdot \mathbf{4} \cdot \mathrm{Cu}_{3}=$ $\mathrm{C}_{296} \mathrm{H}_{358} \mathrm{~N}_{100} \mathrm{O}_{194} \mathrm{P}_{28} \mathrm{Cu}_{3}$ (found: $1353.01(z=7)$; calcd for [3·4+3 $\left.\mathrm{Cu}^{\mathrm{II}}-13 \mathrm{H}\right]^{7-}:$ 1353.02). [duplex] $=100$ $\mu \mathrm{M},\left[\mathrm{CuCl}_{2}\right]=300 \mu \mathrm{M}$ in $20 \mathrm{mM} \mathrm{NH}_{4} \mathrm{OAc}(\mathrm{pH} 7.0)$. Negative mode. Signals ascribed to sodium and ammonium adducts were also observed. The magnified spectrum is shown in Figure 2c. 
(a)

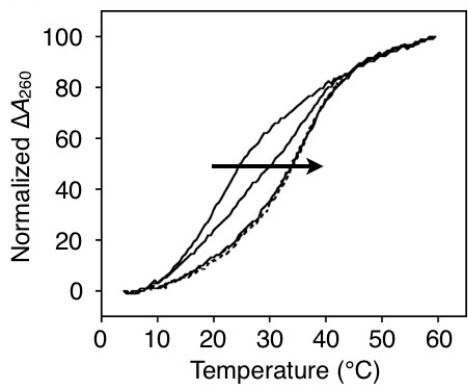

(b)

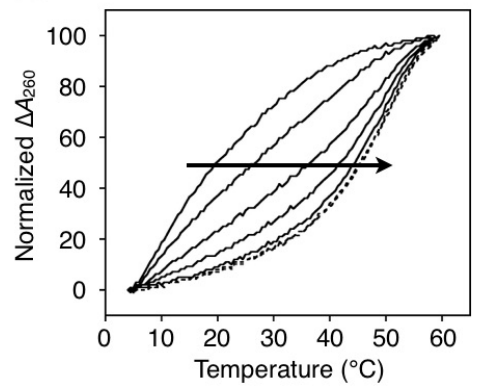

(c)

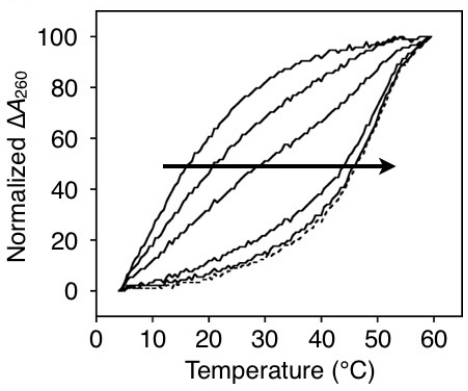

Figure S6. Melting curves of DNA duplexes containing (a) two, (b) four and (c) five caU-caU base pairs $\left(5 \cdot 6,7 \cdot 8\right.$, and $9 \cdot 10$, respectively) in the presence of different concentrations of $\mathrm{Cu}^{\mathrm{II}}$ ions. (a) $\left[\mathrm{Cu}^{\mathrm{II}}\right] /[$ duplex $]=0,1,2$ (solid lines), 3, 4 (dotted lines), (b) $\left[\mathrm{Cu}^{\mathrm{II}}\right] /[$ duplex $]=0,1,2,3,4$ (solid lines), 5, 6 (dotted lines), (c) $\left[\mathrm{Cu}^{\mathrm{II}}\right] /[$ duplex $]=0,1,2,4,5$ (solid lines), 6 (dotted line). [duplex $]=2.0 \mu \mathrm{M}$ in 10 mM HEPES buffer (pH 7.0), $100 \mathrm{mM} \mathrm{NaCl}, 0 .{ }^{\circ} \mathrm{C} \mathrm{min}^{-1}$.

(a)

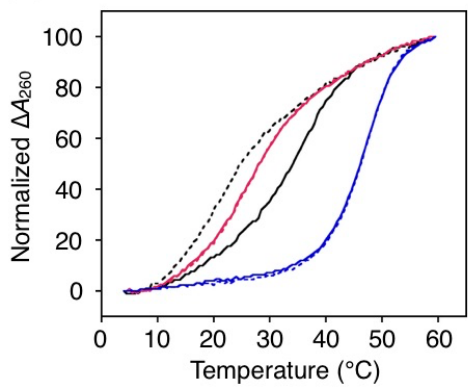

(b)

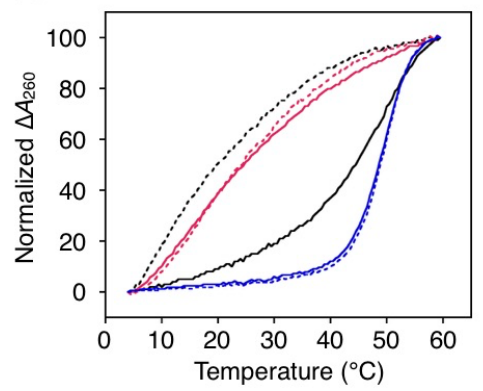

(c)

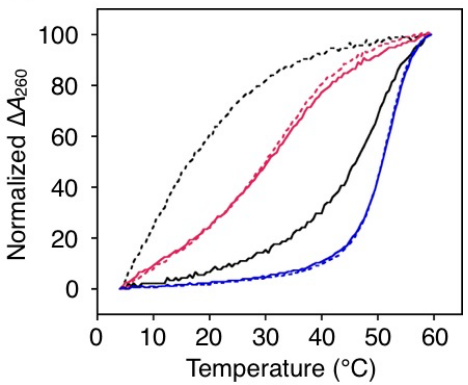

Figure S7. Melting curves of DNA duplexes containing caU-caU (black lines), T-A (blue lines), and $\mathrm{T}-\mathrm{T}$ base pairs (red lines) in the absence (dotted lines) and in the presence (solid lines) of $\mathrm{Cu}^{\mathrm{II}}$ ions. (a)

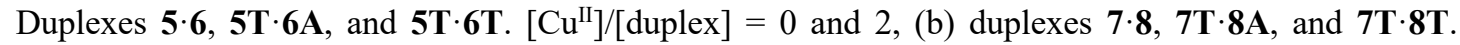
$\left[\mathrm{Cu}^{\mathrm{II}}\right] /[$ duplex $]=0$ and 4 , (c) duplexes $9 \cdot 10,9 \mathrm{~T} \cdot 10 \mathrm{~A}$, and $9 \mathrm{~T} \cdot \mathbf{1 0 T}$. $\left[\mathrm{Cu}^{\mathrm{II}}\right] /[$ duplex $]=0$ and 5 . [duplex] $=2.0 \mu \mathrm{M}$ in $10 \mathrm{mM}$ HEPES buffer (pH 7.0), $100 \mathrm{mM} \mathrm{NaCl}, 0.2^{\circ} \mathrm{C} \mathrm{min}^{-1}$. 
(a)
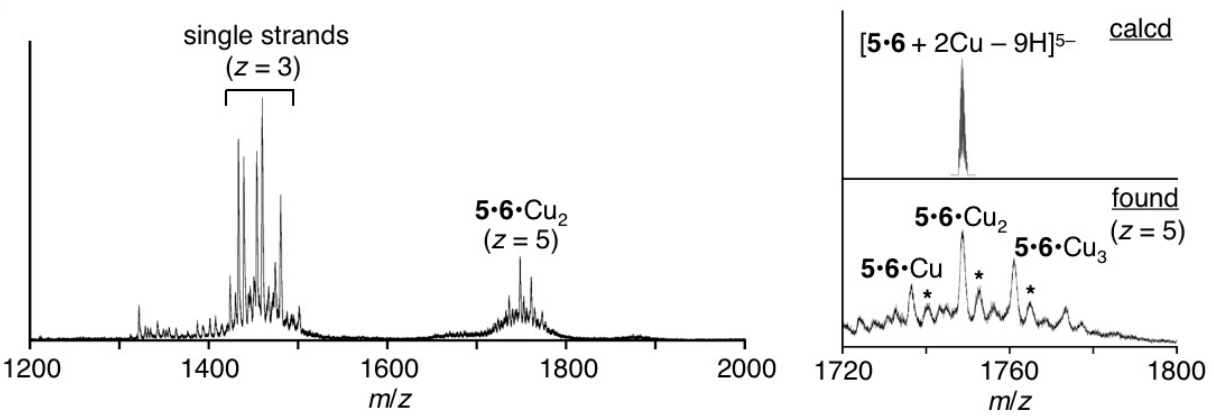

(b)
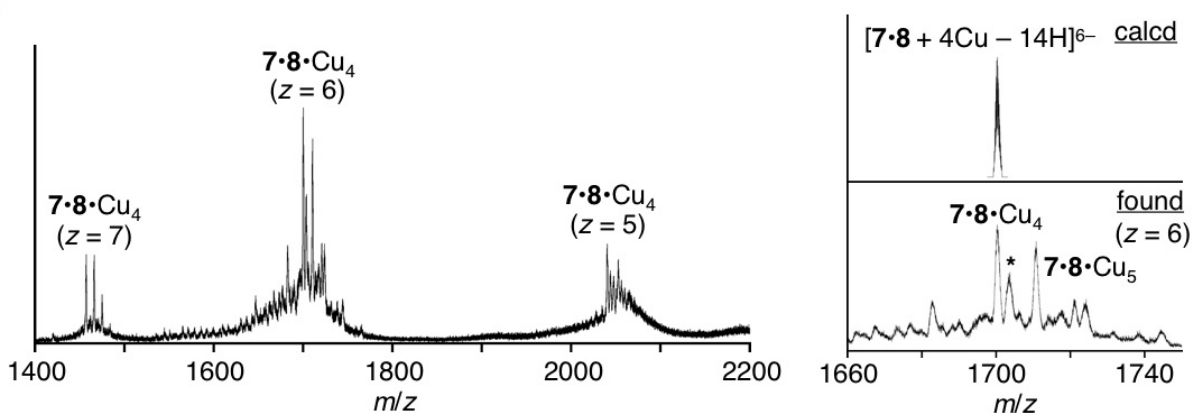

(c)
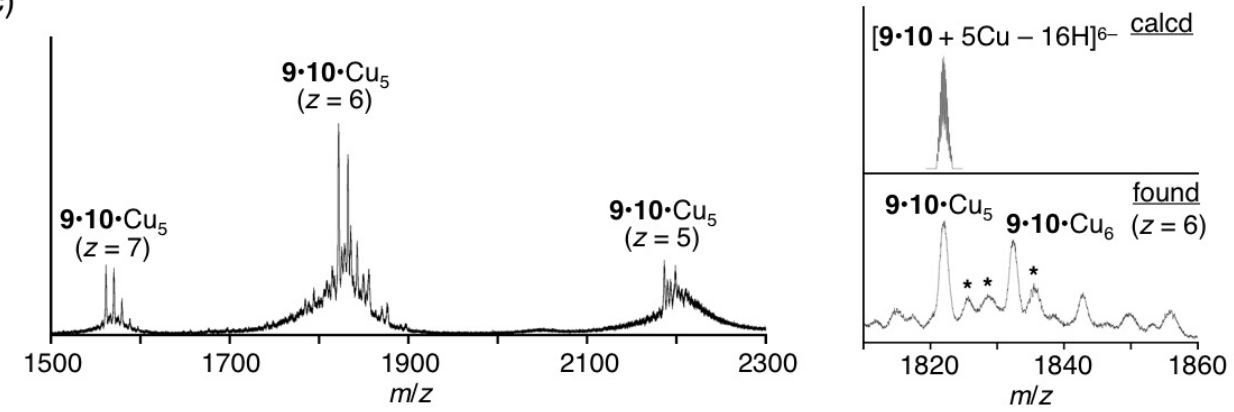

Figure S8. ESI-TOF mass spectra of metallo-DNA duplexes, (a) $5 \cdot 6 \cdot \mathrm{Cu}^{\mathrm{II}}$, (b) $7 \cdot 8 \cdot \mathrm{Cu}^{\mathrm{II}} 4$, and (c) 9.10. $\mathrm{Cu}_{5}{ }_{5}$. (a) $\mathbf{5} \cdot \mathbf{6} \cdot \mathrm{Cu}_{2} \mathrm{II}_{2}=\mathrm{C}_{276} \mathrm{H}_{338} \mathrm{~N}_{96} \mathrm{O}_{176} \mathrm{P}_{26} \mathrm{Cu}_{2}$, (b) $7 \cdot 8 \cdot \mathrm{Cu}_{4} \mathrm{II}_{4}=\mathrm{C}_{316} \mathrm{H}_{378} \mathrm{~N}_{104} \mathrm{O}_{212} \mathrm{P}_{30} \mathrm{Cu}_{4}$, (c) 9·10. $\mathrm{Cu}^{\mathrm{II}_{5}}=\mathrm{C}_{336} \mathrm{H}_{398} \mathrm{~N}_{108} \mathrm{O}_{230} \mathrm{P}_{32} \mathrm{Cu}_{5}$. [duplex] $=100 \mu \mathrm{M}$ in $10 \mathrm{mM} \mathrm{NH} \mathrm{H}_{4} \mathrm{OAc}(\mathrm{pH}$ 7.0). Negative mode. Signals with an asterisk (*) are ascribable to the sodium and/or ammonium adducts.

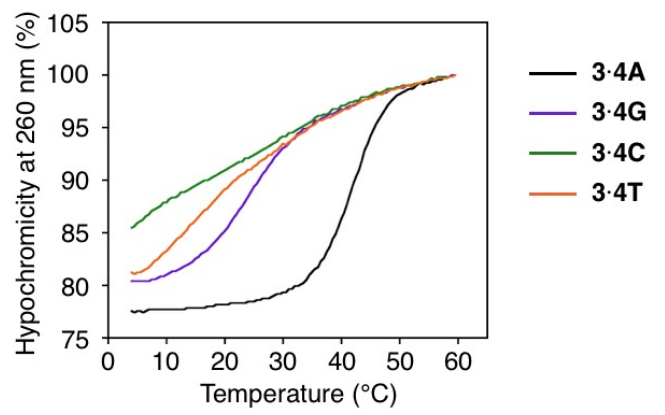

Figure S9. Melting curves of DNA duplexes 3.4X $(X=A, G, C$ and $T)$, containing caU-X pairs. [duplex] $=2.0 \mu \mathrm{M}$, in $10 \mathrm{mM}$ HEPES buffer $\left(\mathrm{pH} \mathrm{7.0)}, 100 \mathrm{mM} \mathrm{NaCl}, 0.2^{\circ} \mathrm{C} \mathrm{min}{ }^{-1}\right.$. The melting temperatures $\left(T_{\mathrm{m}}\right)$ of $\mathbf{3} \cdot \mathbf{4 A}, \mathbf{3} \cdot \mathbf{4 G}$, and $\mathbf{3} \cdot \mathbf{4 T}$ are $41.2 \pm 0.2{ }^{\circ} \mathrm{C}, 25.0 \pm 0.2{ }^{\circ} \mathrm{C}$, and $17.4 \pm 2.0{ }^{\circ} \mathrm{C}$, respectively. The $T_{\mathrm{m}}$ value of $\mathbf{3} \cdot \mathbf{4 C}$ could not be determined. 
(a)

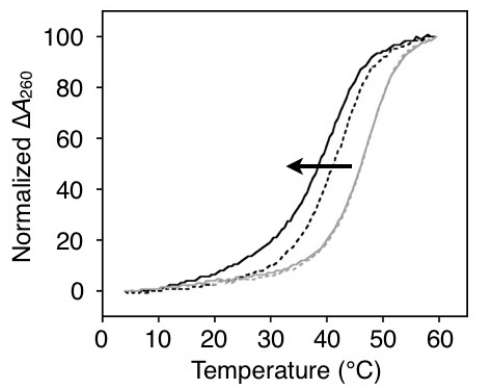

(b)

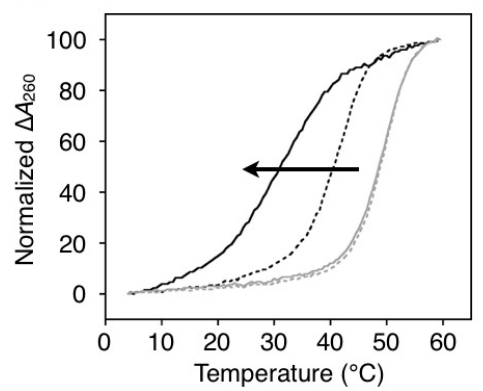

(c)

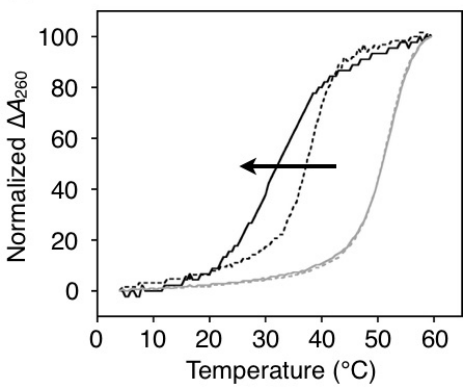

Figure S10. Melting curves of DNA duplexes containing caU-A (black lines) and T-A base pairs (gray lines) in the absence (dotted lines) and in the presence (solid lines) of $\mathrm{Cu}^{\mathrm{II}}$ ions. (a) Duplexes 5.6A, and 5T.6A. $\left[\mathrm{Cu}^{\mathrm{II}}\right] /[$ duplex $]=0$ and 2 , (b) duplexes $7 \cdot 8 \mathbf{A}$ and $7 \mathbf{T} \cdot 8 \mathbf{A} \cdot\left[\mathrm{Cu}^{\mathrm{II}}\right] /[$ duplex $]=0$ and 4 , (c) duplexes $9 \cdot 10 \mathrm{~A}$ and $9 \mathrm{~T} \cdot 10 \mathrm{~A}$. [Cu $\left.\mathrm{Cu}^{\mathrm{II}}\right] /[$ duplex] $=0$ and 5. [duplex] $=2.0 \mu \mathrm{M}$ in $10 \mathrm{mM}$ HEPES buffer (pH 7.0), $100 \mathrm{mM} \mathrm{NaCl}, 0.2^{\circ} \mathrm{C} \mathrm{min}^{-1}$.

(a)

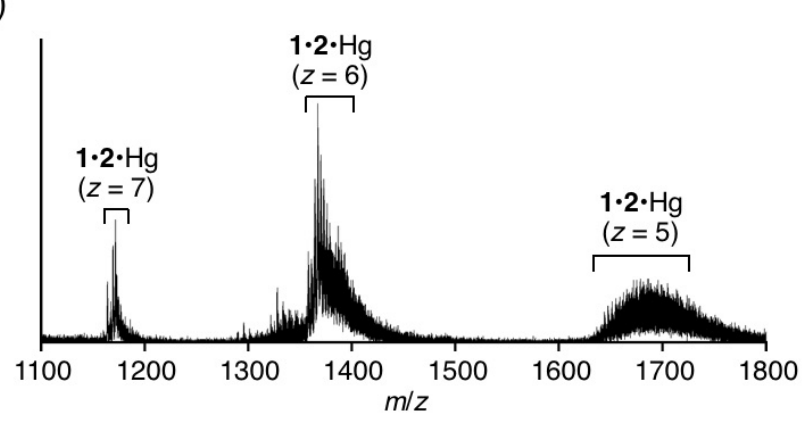

(b)

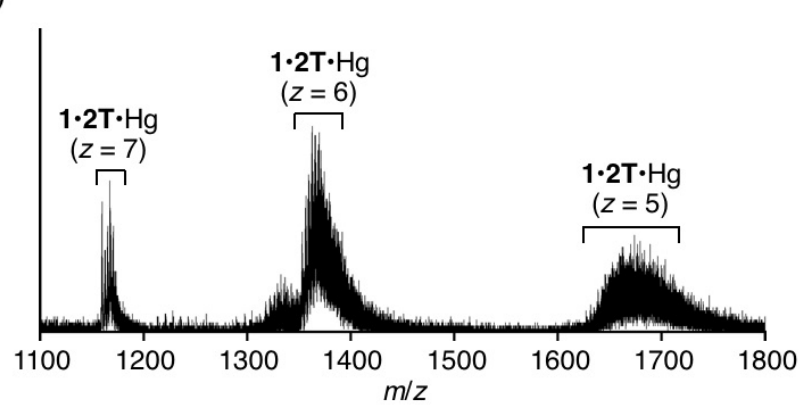

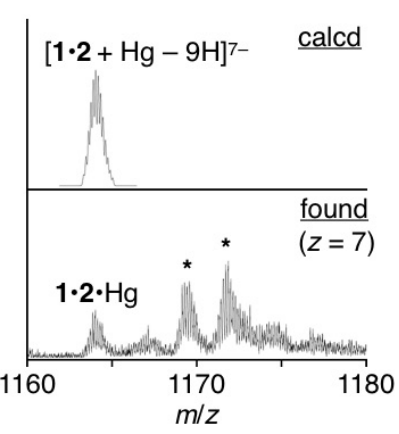

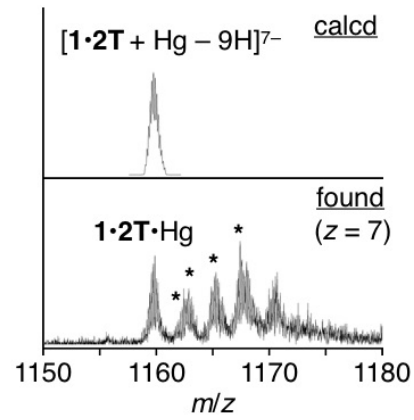

Figure S11. ESI-TOF mass spectra of metallo-DNA duplexes, (a) $1 \cdot \mathbf{2} \cdot \mathrm{Hg}^{\mathrm{II}}$ and (b) $1 \cdot \mathbf{2 T} \cdot \mathrm{Hg}^{\mathrm{II}} \cdot \mathbf{1} \cdot \mathbf{2} \cdot \mathrm{Hg}^{\mathrm{II}}$ $=\mathrm{C}_{256} \mathrm{H}_{318} \mathrm{~N}_{92} \mathrm{O}_{158} \mathrm{P}_{24} \mathrm{Hg}$ (found: $1164.02(z=7)$; calcd for $\left.\left[\mathbf{1} \cdot \mathbf{2}+\mathrm{Hg}^{\mathrm{II}}-9 \mathrm{H}\right]^{7-}: 1164.04\right)$, (b) $\mathbf{1} \cdot \mathbf{2 T} \cdot \mathrm{Hg}^{\mathrm{II}}=$ $\mathrm{C}_{256} \mathrm{H}_{320} \mathrm{~N}_{92} \mathrm{O}_{156} \mathrm{P}_{24} \mathrm{Hg}$ (found: $1159.88(z=7)$; calcd for $\left.\left[\mathbf{1} \cdot \mathbf{2 T}+\mathrm{Hg}^{\mathrm{II}}-9 \mathrm{H}\right]^{7-}: 1159.75\right)$. [duplex] $=100$ $\mu \mathrm{M}$ in $10 \mathrm{mM} \mathrm{NH}_{4} \mathrm{OAc}(\mathrm{pH}$ 7.0). Negative mode. Signals with an asterisk $(*)$ are ascribable to the sodium and/or ammonium adducts. 
(a)

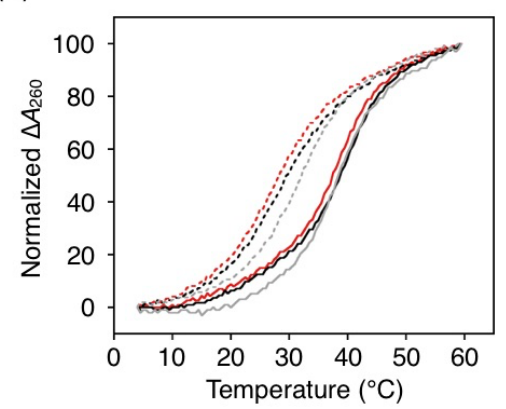

(b)

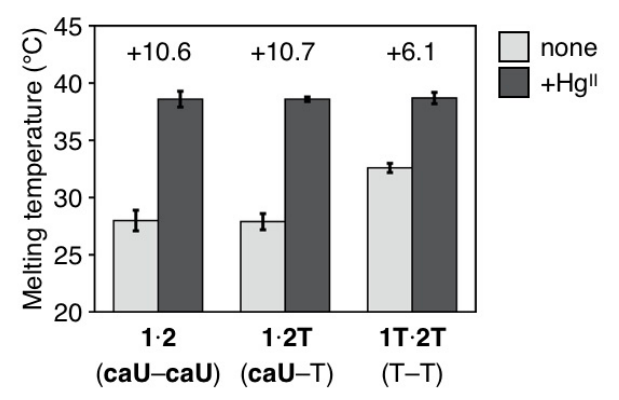

Figure S12. (a) Melting curves of DNA duplexes $\mathbf{1} \cdot \mathbf{2}$ (with a caU-caU pair, red lines), 1·2T (with a caU-T pair, black lines), and 1T·2T (with a T-T pair, gray lines) in the absence (dotted lines) and in the presence (solid lines) of 1 equiv of $\mathrm{Hg}^{\mathrm{II}}$ ions. [duplex] $=2.0 \mu \mathrm{M}$ in $10 \mathrm{mM}$ HEPES buffer $(\mathrm{pH} 7.0$ ), $100 \mathrm{mM} \mathrm{NaNO}_{3}, 0.2^{\circ} \mathrm{C} \mathrm{min}^{-1}$. (b) Melting temperatures. Error bars indicate the standard errors. $\Delta T_{\mathrm{m}}$ values are also shown in the figure. The duplexes $\mathbf{1} \cdot \mathbf{2}$ and $\mathbf{1 \cdot 2 T}$ showed larger $\Delta T_{\mathrm{m}}$ than $\mathbf{1 T} \cdot \mathbf{2 T}$. This could be ascribed to the lower $T_{\mathrm{m}}$ of $\mathbf{1 \cdot 2}$ and $\mathbf{1} \cdot \mathbf{2 T}$ under the metal-free condition, probably because of the electric repulsion of the negatively-charged carboxylate of the caU nucleobases.

(a)

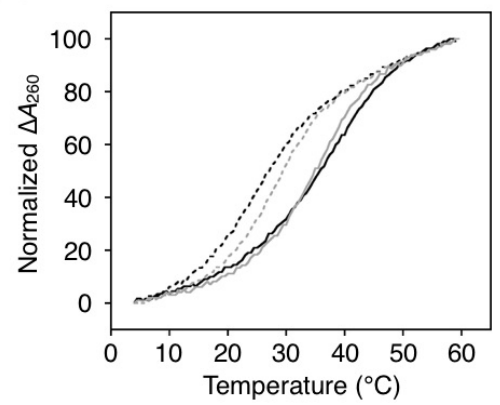

(b)

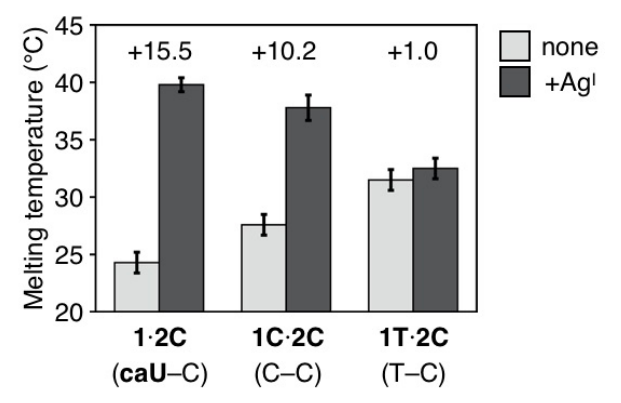

Figure S13. (a) Melting curves of DNA duplexes $\mathbf{1} \cdot \mathbf{2 C}$ (with a caU-C pair, black lines) and $\mathbf{1 C} \cdot \mathbf{2 C}$ (with a $\mathrm{C}-\mathrm{C}$ pair, gray lines) in the absence (dotted lines) and in the presence (solid lines) of 1 equiv of $\mathrm{Ag}^{\mathrm{I}}$ ions. [duplex] $=2.0 \mu \mathrm{M}$ in $10 \mathrm{mM}$ HEPES buffer (pH 7.0), $100 \mathrm{mM} \mathrm{NaNO}, 0.2{ }^{\circ} \mathrm{C} \mathrm{min}^{-1}$. (b) Melting temperatures. Error bars indicate the standard errors. $\Delta T_{\mathrm{m}}$ values are also shown in the figure.
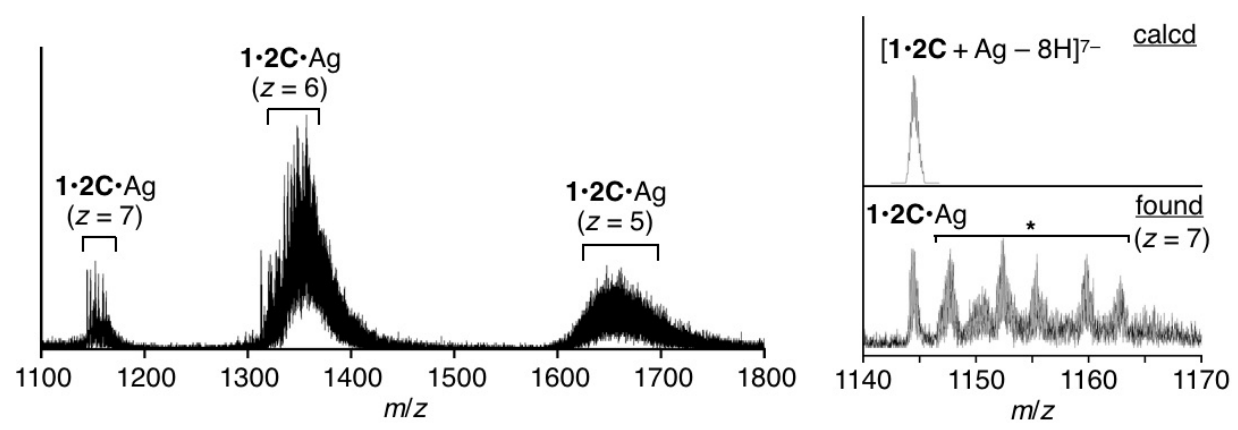

Figure S14. ESI-TOF mass spectrum of metallo-DNA duplex $\mathbf{1} \cdot \mathbf{2 C} \cdot \mathrm{Ag}^{\mathrm{I}} \cdot \mathbf{1} \cdot \mathbf{2} \mathrm{C} \cdot \mathrm{Ag}^{\mathrm{I}}=$ $\mathrm{C}_{255} \mathrm{H}_{320} \mathrm{~N}_{93} \mathrm{O}_{155} \mathrm{P}_{24} \mathrm{Ag}$ (found: $1144.43(z=7)$; calcd for [1·2C+AgI-8H] ${ }^{7-}$ : 1144.46). [duplex] $=100$ $\mu \mathrm{M}$ in $10 \mathrm{mM} \mathrm{NH} 4 \mathrm{OAc}(\mathrm{pH} 7.0$ ). Negative mode. Signals with an asterisk $(*)$ are ascribable to the sodium and/or ammonium adducts. 

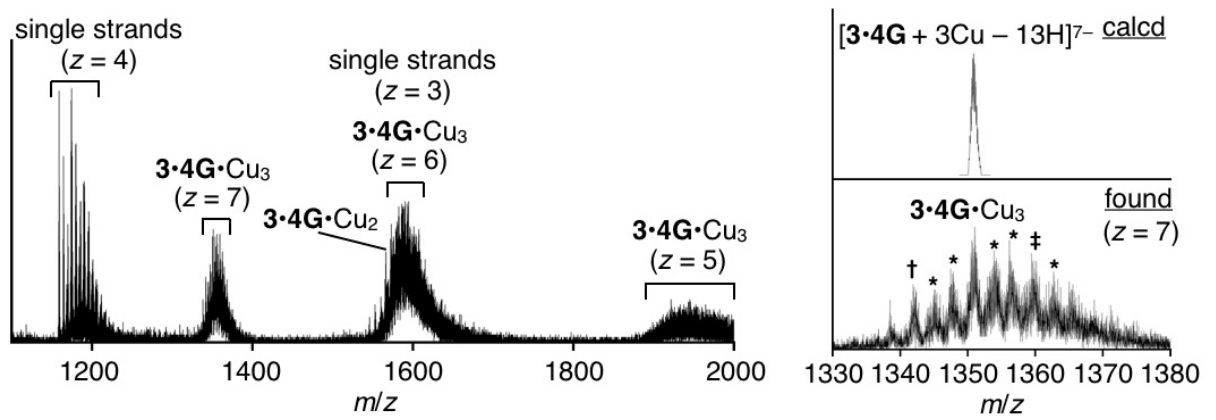

Figure S15. ESI-TOF mass spectrum of metallo-DNA duplex $\mathbf{3} \cdot \mathbf{4 G} \cdot \mathrm{Cu}^{\mathrm{II}} 3 . \quad \mathbf{3} \cdot \mathbf{4 G} \cdot \mathrm{Cu}_{3} \mathrm{II}_{3}=$ $\mathrm{C}_{296} \mathrm{H}_{361} \mathrm{~N}_{109} \mathrm{O}_{185} \mathrm{P}_{28} \mathrm{Cu}_{3}$ (found: $1351.05(z=7)$; calcd for $\left[\mathbf{3} \cdot \mathbf{4 G}+3 \mathrm{Cu}^{\mathrm{II}}-13 \mathrm{H}\right]^{7}:$ : 1350.89). [duplex] $=$ $100 \mu \mathrm{M}$ in $10 \mathrm{mM} \mathrm{NH} \mathrm{H}_{4} \mathrm{OAc}\left(\mathrm{pH}\right.$ 7.0). Negative mode. Signals corresponding to $\mathbf{3} \cdot \mathbf{4 G} \cdot \mathrm{Cu}_{2}{ }^{\mathrm{II}_{2}}(\dagger)$ and 3.4G. $\mathrm{Cu}_{4}{ }_{4}(\ddagger)$ are also observed. Signals with an asterisk $(*)$ are ascribable to the sodium and/or ammonium adducts.

(a)

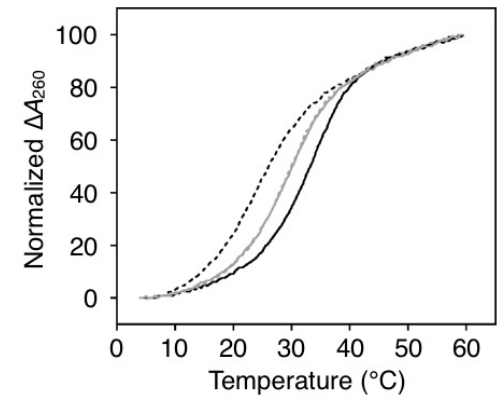

(b)

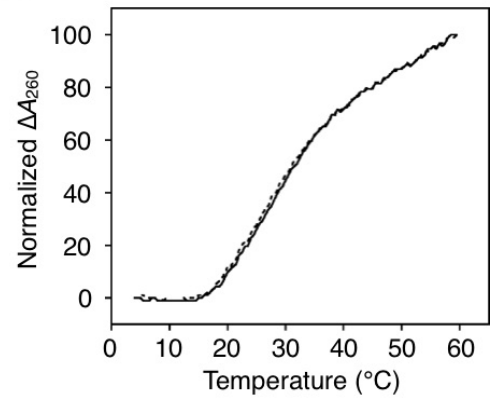

Figure S16. Melting curves of (a) DNA duplexes 3.4G (black lines) and 3T·4G (gray lines) and (b) duplex 1.2G in the absence (dotted lines) and in the presence (solid lines) of $\mathrm{Cu}^{\mathrm{II}}$ ions. (a) $\left[\mathrm{Cu}^{\mathrm{II}}\right] /[$ duplex $]=0$ and 3 , (b) $\left[\mathrm{Cu}^{\mathrm{II}}\right] /[$ duplex $]=0$ and 1 . [duplex $]=2.0 \mu \mathrm{M}$ in $10 \mathrm{mM}$ HEPES buffer (pH 7.0), $100 \mathrm{mM} \mathrm{NaCl}, 0.2^{\circ} \mathrm{C} \mathrm{min}^{-1}$.

(a)

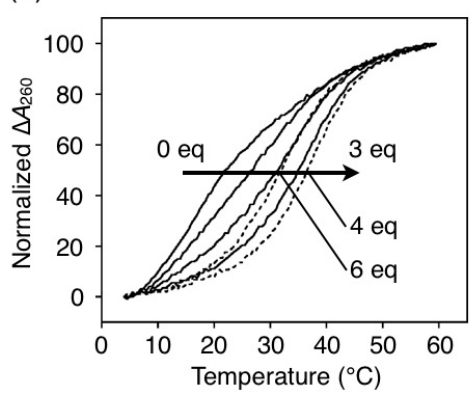

(b)

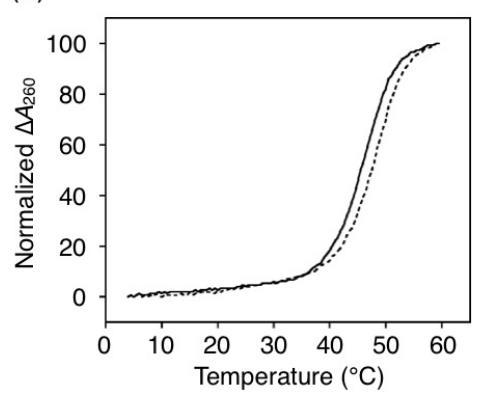

(c)

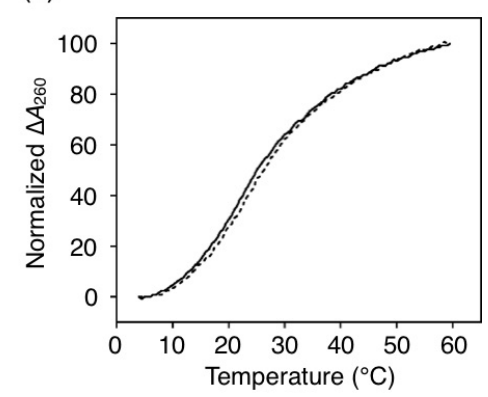

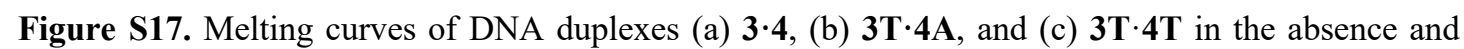
presence of $\mathrm{Gd}^{\mathrm{III}}$ ions. (a) $\left[\mathrm{Gd}^{\mathrm{III}}\right] /[$ duplex $]=0,1,2,3$ (solid lines), 4, and 6 (dotted lines), (b,c) $\left[\mathrm{Gd}^{\mathrm{III}}\right] /[$ duplex $]=0$ (dotted lines) and 3 (solid lines). [duplex $]=2.0 \mu \mathrm{M}$ in $10 \mathrm{mM}$ HEPES buffer $(\mathrm{pH}$ 7.0), $100 \mathrm{mM} \mathrm{NaCl}, 0.2^{\circ} \mathrm{C} \mathrm{min}^{-1}$. 

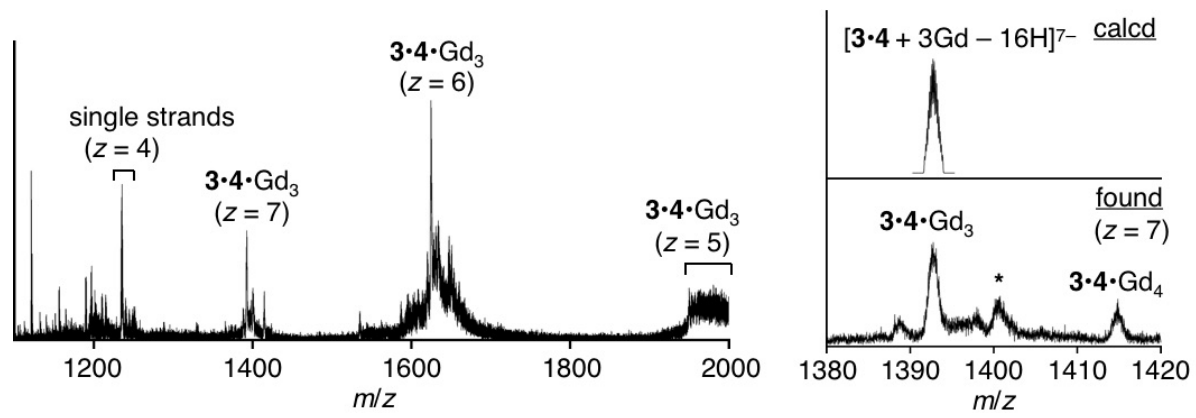

Figure S18. ESI-TOF mass spectrum of metallo-DNA duplex $\mathbf{3} \cdot \mathbf{4} \cdot \mathrm{Gd}^{\mathrm{III}}{ }_{3} . \quad \mathbf{3} \cdot \mathbf{4} \cdot \mathrm{Gd}^{\mathrm{III}}{ }_{3}=$ $\mathrm{C}_{296} \mathrm{H}_{355} \mathrm{~N}_{100} \mathrm{O}_{194} \mathrm{P}_{28} \mathrm{Gd}_{3}$. [duplex] $=100 \mu \mathrm{M}$ in $10 \mathrm{mM} \mathrm{NH} 4 \mathrm{OAc}(\mathrm{pH}$ 7.0). Negative mode. The signal with an asterisk $(*)$ is ascribable to an acetate adduct.

(a)

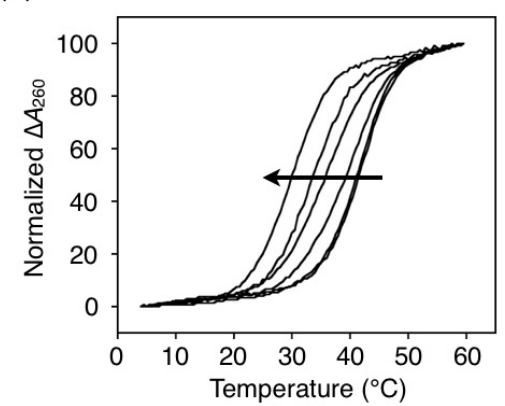

(b)

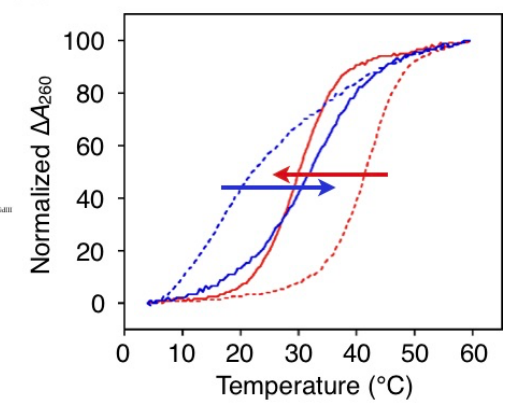

Figure S19. (a) Melting profiles of duplex 3.4A in the presence of different concentration of $\mathrm{Gd}^{\mathrm{III}}$ ions. $\left[\mathrm{Gd}^{\mathrm{III}}\right] /[$ duplex] $]=0,1,2,3,4$, and 6. (b) Melting curves of duplex 3.4 (blue) and 3.4A (red) in the absence (dotted lines) and presence of 6 equiv of $\mathrm{Gd}^{\mathrm{III}}$ ions (solid lines).
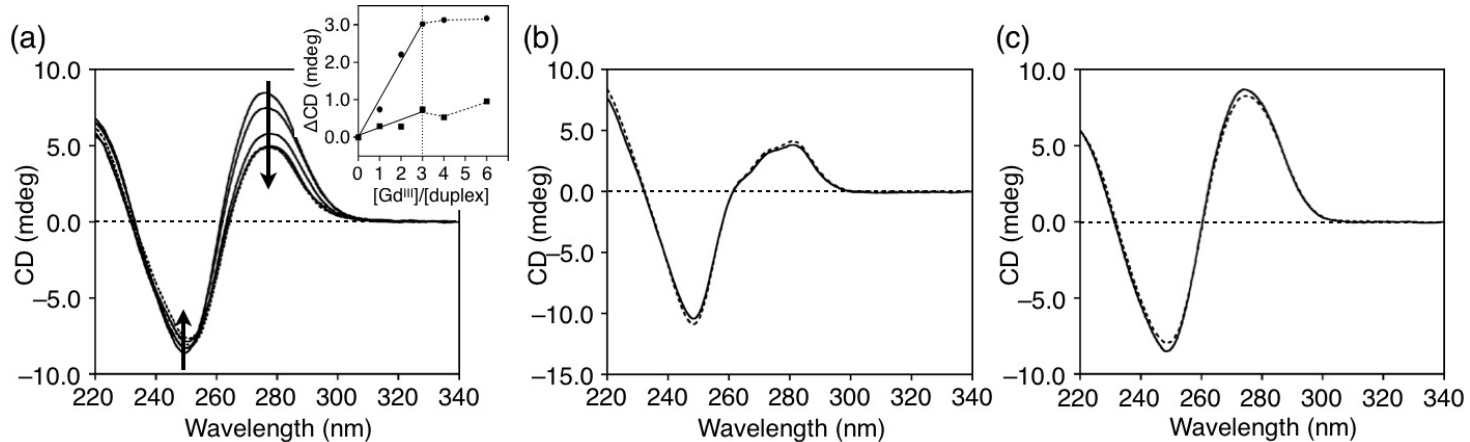

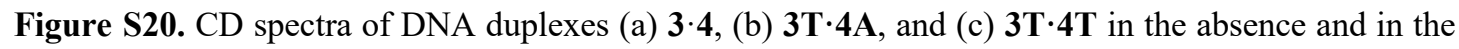
presence of $\mathrm{Gd}^{\mathrm{III}}$ ions. (a) $\left[\mathrm{Gd}^{\mathrm{III}}\right] /[$ duplex $]=0,1,2,3$ (solid lines), 4, and 6 (dotted lines), (b,c) $\left[\mathrm{Gd}^{\mathrm{III}}\right] /[$ duplex $]=0$ (dotted lines) and 3 (solid lines). [duplex $]=2.0 \mu \mathrm{M}$ in $10 \mathrm{mM}$ HEPES buffer (pH 7.0), $100 \mathrm{mM} \mathrm{NaCl}, l=1.0 \mathrm{~cm}, 5^{\circ} \mathrm{C}$. 
(a)

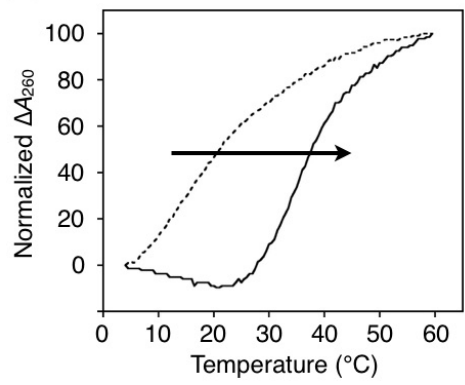

(b)

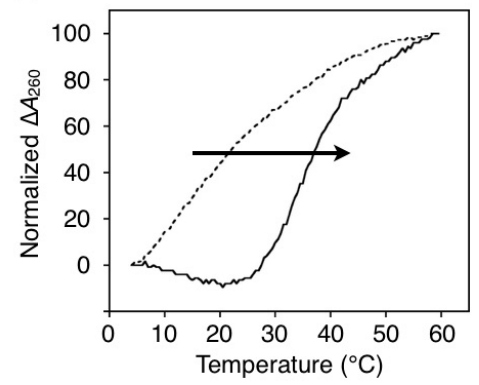

(c)

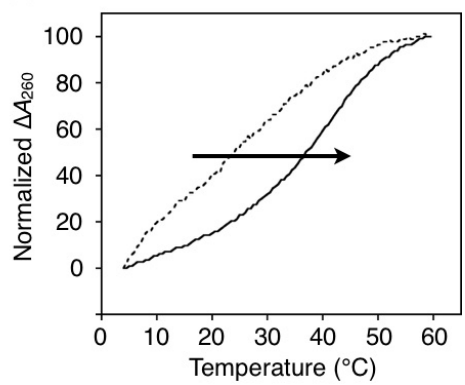

Figure S21. Melting curves of DNA duplexes (a) 3.4, (b) 3.4T, and (c) 3.4C in the absence and presence of $\mathrm{Hg}^{\mathrm{II}}$ or $\mathrm{Ag}^{\mathrm{I}}$ ions. (a,b) $\left[\mathrm{Hg}^{\mathrm{II}}\right] /[$ duplex $]=0$ (dashed line) and 3 (solid line), (c) $\left[\mathrm{Ag}^{\mathrm{I}}\right] /[\mathrm{duplex}]$ $=0$ (dashed line) and 3 (solid line). [duplex] $=2.0 \mu \mathrm{M}$ in $10 \mathrm{mM}$ HEPES buffer (pH 7.0), $100 \mathrm{mM}$ $\mathrm{NaNO}_{3}, 0.2{ }^{\circ} \mathrm{C} \mathrm{min}^{-1}$.

\section{Supplementary tables}

Table S1 Duplex melting temperatures in the presence of $\mathrm{Cu}^{\mathrm{II}}$ ions. $^{a}$

\begin{tabular}{lccccc}
\hline & Metal-free & \multicolumn{2}{c}{3 equiv of $\mathrm{Cu}^{\text {II }}$} & \multicolumn{2}{c}{ 6 equiv of $\mathrm{Cu}^{\text {II }}$} \\
\cline { 2 - 6 } & $T_{\mathrm{m}} /{ }^{\circ} \mathrm{C}^{b}$ & $T_{\mathrm{m}} /{ }^{\circ} \mathrm{C}^{b}$ & $\Delta T_{\mathrm{m}} /{ }^{\circ} \mathrm{C}^{c}$ & $T_{\mathrm{m}} /{ }^{\circ} \mathrm{C}^{b}$ & $\Delta T_{\mathrm{m}} /{ }^{\circ} \mathrm{C}^{c}$ \\
\hline 3.4 & $17.7 \pm 0.2$ & $48.4 \pm 0.6$ & +30.7 & $47.0 \pm 0.1$ & +29.3 \\
3T·4T & $22.2 \pm 0.3$ & $22.9 \pm 0.9$ & +0.7 & - & - \\
3T·4A & $48.7 \pm 0.9$ & $49.5 \pm 0.3$ & +0.8 & - & - \\
\hline 3·4A & $41.2 \pm 0.2$ & $39.4 \pm 0.1$ & -1.8 & $33.9 \pm 0.9$ & -7.3 \\
\hline
\end{tabular}

${ }^{a}$ Average of at least 3 runs after annealing $\left(1.0^{\circ} \mathrm{C} \mathrm{min}^{-1}\right)$ with standard errors. ${ }^{b}$ Melting temperatures $\left(T_{\mathrm{m}}\right)$ were determined as the temperature at the inflection point of melting curves. ${ }^{c} \Delta T_{\mathrm{m}}$ represents the difference in the $T_{\mathrm{m}}$ value relative to those of the metalfree DNA duplexes.

Table S2 Duplex melting temperatures in the presence of $\mathrm{Hg}^{\mathrm{II}}$ ions. ${ }^{a}$

\begin{tabular}{lccc}
\hline & Metal-free & \multicolumn{2}{c}{1 equiv of $\mathrm{Hg}^{\mathrm{II}}$} \\
\cline { 2 - 4 } & $T_{\mathrm{m}} /{ }^{\circ} \mathrm{C}^{b}$ & $T_{\mathrm{m}} /{ }^{\circ} \mathrm{C}^{b}$ & $\Delta T_{\mathrm{m}} /{ }^{\circ} \mathrm{C}^{c}$ \\
\hline $\mathbf{1 \cdot 2}$ & $28.0 \pm 0.9$ & $38.6 \pm 0.7$ & +10.6 \\
$\mathbf{1 \cdot 2 T}$ & $27.9 \pm 0.7$ & $38.6 \pm 0.2$ & +10.7 \\
$\mathbf{1 \cdot 2 A}$ & $43.9 \pm 1.0$ & $41.0 \pm 0.4$ & -2.9 \\
$\mathbf{1 \cdot 2 G}$ & $27.5 \pm 0.3$ & $23.1 \pm 0.5$ & -4.4 \\
$\mathbf{1 \cdot 2 C}$ & $24.3 \pm 0.9$ & $23.9 \pm 0.5$ & -0.4 \\
\hline $\mathbf{1 T \cdot 2 T}$ & $32.6 \pm 0.4$ & $38.7 \pm 0.5$ & +6.1 \\
$\mathbf{1 T \cdot 2 A}$ & $45.0 \pm 0.6$ & $44.3 \pm 0.1$ & -0.7 \\
\hline
\end{tabular}

${ }^{a}$ Average of at least 3 runs after annealing $\left(1.0^{\circ} \mathrm{C} \mathrm{min}{ }^{-1}\right)$ with standard errors. ${ }^{b}$ Melting temperatures $\left(T_{\mathrm{m}}\right)$ were determined as the temperature at the inflection point of melting curves. ${ }^{c} \Delta T_{\mathrm{m}}$ represents the difference in the $T_{\mathrm{m}}$ value relative to those of the metalfree DNA duplexes. 
Table S3 Duplex melting temperatures in the presence of $\mathrm{Ag}^{\mathrm{I}}$ ions. ${ }^{a}$

\begin{tabular}{lccc}
\hline & Metal-free & \multicolumn{2}{c}{1 equiv of $\mathrm{Ag}^{\mathrm{I}}$} \\
\cline { 2 - 4 } & $T_{\mathrm{m}} /{ }^{\circ} \mathrm{C}^{b}$ & $T_{\mathrm{m}} /{ }^{\circ} \mathrm{C}^{b}$ & $\Delta T_{\mathrm{m}} /{ }^{\circ} \mathrm{C}^{c}$ \\
\hline $\mathbf{1 \cdot 2}$ & $28.0 \pm 0.9$ & $29.4 \pm 1.1$ & +1.4 \\
$\mathbf{1 \cdot 2 T}$ & $27.9 \pm 0.7$ & $31.0 \pm 0.6$ & +3.1 \\
$\mathbf{1 \cdot 2 A}$ & $43.9 \pm 1.0$ & $44.0 \pm 0.2$ & +0.1 \\
$\mathbf{1 \cdot 2 G}$ & $27.5 \pm 0.3$ & $30.7 \pm 0.6$ & +3.2 \\
\hline $\mathbf{1 \cdot 2 C}$ & $24.3 \pm 0.9$ & $39.8 \pm 0.6$ & +15.5 \\
$\mathbf{1 T} \cdot \mathbf{1 C} \cdot \mathbf{C}$ & $31.5 \pm 0.9$ & $32.5 \pm 0.9$ & +1.0 \\
$\mathbf{1 T} \cdot \mathbf{2 A}$ & $27.6 \pm 0.9$ & $37.8 \pm 1.1$ & +10.2 \\
\hline
\end{tabular}

${ }^{a}$ Average of at least 3 runs after annealing $\left(1.0^{\circ} \mathrm{C} \mathrm{min}^{-1}\right)$ with standard errors. ${ }^{b}$ Melting temperatures $\left(T_{\mathrm{m}}\right)$ were determined as the temperature at the inflection point of melting curves. ${ }^{c} \Delta T_{\mathrm{m}}$ represents the difference in the $T_{\mathrm{m}}$ value relative to those of the metalfree DNA duplexes.

Table S4 Duplex melting temperatures in the presence of caU-Cu ${ }^{\mathrm{II}}-\mathrm{G}$ pairing. ${ }^{a}$

\begin{tabular}{lccc}
\hline & Metal-free & \multicolumn{2}{c}{3 equiv of $\mathrm{Cu}^{\mathrm{II}}$} \\
\cline { 2 - 4 } & $T_{\mathrm{m}} /{ }^{\circ} \mathrm{C}^{b}$ & $T_{\mathrm{m}} /{ }^{\circ} \mathrm{C}^{b}$ & $\Delta T_{\mathrm{m}} /{ }^{\circ} \mathrm{C}^{c}$ \\
\hline 3.4G & $25.0 \pm 0.2$ & $33.3 \pm 0.4$ & +8.3 \\
3T-4G & $28.6 \pm 0.4$ & $29.8 \pm 0.6$ & +1.2 \\
3.4dzG & $26.0 \pm 0.7$ & $29.5 \pm 0.2$ & +3.5 \\
\hline
\end{tabular}

${ }^{a}$ Average of at least 3 runs after annealing $\left(1.0^{\circ} \mathrm{C} \mathrm{min}^{-1}\right)$ with standard errors. ${ }^{b}$ Melting temperatures $\left(T_{\mathrm{m}}\right)$ were determined as the temperature at the inflection point of melting curves. ${ }^{c} \Delta T_{\mathrm{m}}$ represents the difference in the $T_{\mathrm{m}}$ value relative to those of the metalfree DNA duplexes.

Table S5 Duplex melting temperatures in the presence of $\mathrm{Gd}^{\mathrm{II}}$ ions. ${ }^{a}$

\begin{tabular}{lccccc}
\hline & Metal-free & \multicolumn{2}{c}{3 equiv of $\mathrm{Gd}^{\mathrm{III}}$} & \multicolumn{2}{c}{6 equiv of $\mathrm{Gd}^{\mathrm{III}}$} \\
\cline { 2 - 6 } & $T_{\mathrm{m}} /{ }^{\circ} \mathrm{C}^{b}$ & $T_{\mathrm{m}} /{ }^{\circ} \mathrm{C}^{b}$ & $\Delta T_{\mathrm{m}} /{ }^{\circ} \mathrm{C}^{c}$ & $T_{\mathrm{m}} /{ }^{\circ} \mathrm{C}^{b}$ & $\Delta T_{\mathrm{m}} /{ }^{\circ} \mathrm{C}^{c}$ \\
\hline 3·4 & $17.7 \pm 0.2$ & $37.1 \pm 0.9$ & +19.4 & $33.0 \pm 0.4$ & +15.3 \\
3T·4T & $22.2 \pm 0.3$ & $23.7 \pm 0.8$ & +1.5 & - & - \\
3T·4A & $48.7 \pm 0.9$ & $47.2 \pm 0.9$ & -1.5 & - & - \\
\hline 3·4A & $41.2 \pm 0.2$ & $35.2 \pm 0.6$ & -6.0 & $32.2 \pm 1.0$ & -9.0 \\
\hline
\end{tabular}

${ }^{a}$ Average of at least 3 runs after annealing $\left(1.0^{\circ} \mathrm{C} \mathrm{min}^{-1}\right)$ with standard errors. ${ }^{b}$ Melting temperatures $\left(T_{\mathrm{m}}\right)$ were determined as the temperature at the inflection point of melting curves. ${ }^{c} \Delta T_{\mathrm{m}}$ represents the difference in the $T_{\mathrm{m}}$ value relative to those of the metalfree DNA duplexes.

\section{References}

(1) Berthod, T.; Pétillot, Y.; Guy, A.; Cadet, J.; Molko, D. Synthesis of Oligonucleotides Containing 5-Carboxy-2'-deoxyuridine at Defined Sites. J. Org. Chem. 1996, 61, 6075-6078.

(2) Guerniou, V.; Gasparutto, D; Sauvaigo, S; Favier, A.; Cadet, J. New Synthesis of 5Carboxy-2'-deoxyuridine and Its Incorporation into Synthetic Oligonucleotides. Nucleosides, Nucleotides and Nucleic Acids. 2003, 22, 1073-1075. 